\title{
Black Plastic Tarps Advance Organic Reduced Tillage I: Impact on Soils, Weed Seed Survival, and Crop Residue
}

\author{
Haley Rylander \\ Horticulture Section, School of Integrative Plant Science, Cornell University, \\ 135 Plant Science Building, Ithaca, NY 14853
}

\author{
Anusuya Rangarajan \\ Horticulture, Cornell University, 15 G Plant Science Building, Ithaca, NY \\ 14853
}

\begin{abstract}
Ryan M. Maher
Horticulture Section, School of Integrative Plant Science, Cornell University, 135 Plant Science Building, Ithaca, NY 14853
\end{abstract}

\author{
Mark G. Hutton and Nicholas W. Rowley \\ University of Maine School of Food and Agriculture and University of Maine \\ Cooperative Extension, Highmoor Farm, P.O. Box 179, Monmouth, ME \\ 04259
}

\section{Margaret T. McGrath and Zachary F. Sexton \\ Plant Pathology and Plant-Microbe Biology Section, School of Integrative Plant Science, Cornell University, Long Island Horticultural Research and Extension Center, 3059 Sound Avenue, Riverhead, NY 11901 Additional index words. polyethylene, nitrogen, moisture, temperature, Chenopodium album,
Amaranthus powellii}

\begin{abstract}
Intensive tillage degrades soil structure, decreases soil organic matter, and can cause soil compaction and erosion over time. Organic vegetable farmers are often dependent on tillage to incorporate crop residue, control weeds, and prepare seedbeds. Black, impermeable, polyethylene tarps applied on the soil surface and removed at planting can help suppress weeds before planting and reduce farmers' reliance on tillage. However, little is known about how black tarps affect planting conditions and how they can be used to advance reduced tillage production systems. This study investigated the effects of tarp use and tarp duration on the soil environment, surface cover crop residue, and weed suppression to assess the efficacy of using tarps to improve reduced- and no-till practices for organic vegetable production. Experiments were conducted at three sites in the northeastern United States (Freeville, NY; Riverhead, NY; and Monmouth, ME) for 2 years. Following the termination of an oat cover crop, tarps were applied over untilled soils and left in place for four time periods: untarped (control), 3 to 5 weeks (short), 6 to 8 weeks (mid), and 10 or more weeks (long) before two removal dates. Soil moisture and temperature, cover crop residue, soil inorganic nitrogen, weed seed survival, and weed percent cover were measured after tarp removal. Soil moisture and temperature were generally higher under tarps at the time of removal compared with untarped areas at $10 \%$ to $55 \%$ and 1 to $3{ }^{\circ} \mathrm{C}$, respectively, but the effects were inconsistent. Tarps significantly increased soil nitrate concentrations by 2-times to 21-times with longer tarp durations, resulting in higher concentrations compared with untarped controls. Tarps did not affect the amount of soil covered by cover crop residue and had no consistent effects on weed seed survival of Amaranthus powellii S. Wats. or Chenopodium album L., two common annual weed species in the Northeast. Tarping for at least 3 weeks reduced the weed percent cover by $95 \%$ to $100 \%$ at the time of removal. Increasing tarp duration beyond 3 weeks did not affect any measures except soil nitrate concentrations. These results indicate that tarps can facilitate the use of reduced-till and no-till practices for organic vegetables by creating a nutrient-rich and moist soil environment free of emerged weeds before planting without soil disturbance.
\end{abstract}

The adoption of reduced-till practices for organic vegetable systems is hindered by the lack of access to appropriately scaled equipment, challenging weed management, residue interference in field operations, poor crop establishment, and variable yields (Lowry and Brainard, 2017). Tillage suppresses weeds, incorporates crop residue, and prepares smooth seedbeds for planting. Intensive and frequent tillage, however, causes long-term soil degradation, thereby decreasing aggregate stability, water retention and infiltration, and soil organic matter and microbial populations (Franzluebbers, 2002; Hungria et al., 2009; TerArvest et al., 2015; Want et al., 2014).

Tarping has emerged as a practice used by small-scale organic farmers in the northeastern United States to reduce tillage by decreasing weed pressure and maintaining prepared beds before planting. Tarps are reusable sheets of $0.15-\mathrm{mm}$ (5-6 mil) opaque polyethylene impermeable to water and sized to cover multiple crop rows at one time. Farmers typically apply tarps by hand to undisturbed or tilled soil, and they secure the edges with sandbags or by burying them. They remain in place for weeks or months before a cash crop. Reported benefits of tarps include reduced weeds, increased degradation of cover crop residue, and higher crop yields (Birthisel, 2018; Lounsbury et al., 2018; Rylander et al., 2020). These tarping benefits may advance organic reduced tillage systems by decreasing tillage depth, intensity, and frequency before planting, but there are few research studies about tarping, and tarping effects on weed dynamics and soil processes are poorly understood.

The effects of tillage on weeds are species-specific and dependent on the germination requirements (light, temperature, nutrients, and soil moisture), life cycle, and dispersal mechanisms of individual species (Chauhan et al., 2012). Tillage can induce dormancy of annual weed seeds by burying them and/or stimulate germination by bringing them to the soil surface. Tillage also kills emerged annual weeds by chopping them and leaving them to dry out on the soil surface (Nakamoto et al., 2006). Tarping can kill emerged weeds (Birthisel, 2018; Lounsbury et al., 2018) and could help farmers manage weed seed banks for reduced-till systems, where $50 \%$ to $85 \%$ of the weed seed bank is in the upper $5 \mathrm{~cm}$ of soil (Chauhan et al., 2006; Clements et al., 1996). However, the effects of tarps on weeds and weed seed banks are likely species-specific and remain relatively unknown.

Tarping could alter soil temperatures, with consequences for weed seedling and weed seed survival. Numerous studies have reported that soil solarization with clear plastic sheets before planting kills many annual weed species by heating the soil to lethal levels (Candido et al., 2011; Egley, 1983; Kanaan et al., 2018; Khan et al., 2012; Linke, 1994; Samtani et al., 2017). Soil temperatures under clear plastic must reach 40 to $65^{\circ} \mathrm{C}$ to render weed seeds unviable and kill emerged weeds (Abu-Gharbieh et al., 1988; Egley, 1983; Oz, 2018); these soil temperatures are common in warmer climates with more sunlight than that occurring in the Northeast. In Maine, black tarps increased the average soil temperatures by 1 to $6{ }^{\circ} \mathrm{C}$ compared with bare ground from July through September, with a maximum temperature of $41{ }^{\circ} \mathrm{C}$ (Birthisel, 2018). Black tarps did not heat the soil as much as clear plastic, which reached temperatures as high as $50{ }^{\circ} \mathrm{C}$. In contrast, black tarps over a roller-crimped cover crop in New 
Hampshire in June lowered average soil temperature relative to clear tarp or no-tarp treatments (Lounsbury et al., 2018); soil temperatures under black tarps never exceeded $25^{\circ} \mathrm{C}$, and those under clear plastic never exceeded $40{ }^{\circ} \mathrm{C}$.

Reduced-till systems leave residue from past crops and cover crops on the surface of the soil. Although surface residue can provide multiple soil benefits, including protecting the surface from erosion and increasing soil moisture retention (Alliaume et al., 2017; Laufer et al., 2016; Tebrügge and Düring, 1999), it can interfere with planting and cultivation equipment and compromise seed bed quality (Raoufat and Mahmoodieh, 2005), especially for small seeded crops. Farmers report less crop residue under tarps (Liz Martin, personal communication), but there is little research documenting how tarps affect residue degradation across different fields and soils. In New Hampshire, both clear and black tarps killed a winter rye/hairy vetch cover crop within 2 weeks, and black tarps reduced crop residue more than clear tarp and no-tarp treatments (Lounsbury et al., 2018).

Tarps are impermeable and could drive changes in soil moisture availability and nutrient dynamics for the following crop. Farmers commonly use thin polyethylene mulch films during crop growth to reduce weed emergence, elevate soil temperatures ( 3 to $6{ }^{\circ} \mathrm{C}$ compared with uncovered soil), conserve soil moisture, and reduce nutrient leaching from rainfall (Canul-Tun et al., 2017; Fan et al., 2017; Filipovic et al., 2016; Fritz, 2012; Gu et al., 2018; Kasirajan and Ngouajio, 2012; Ramakrishna et al., 2006; Yu et al., 2018; Zhang et al., 2017). When applied by farmers before crop planting, tarps could similarly moderate soil moisture by preventing evaporation and avoid oversaturation after rain events. Soil moisture was more stable under black tarps compared with uncovered soil following rainfall events (Lounsbury et al., 2018). Nitrate is extremely prone to leaching, and the severity of leaching is correlated with rainfall ( $\mathrm{Lu}$ et al., 2019). Tarps may help reduce rainwater infiltration and subsequent nitrate leaching in soils, although some water could infiltrate at the edges of tarps if the edges are not buried.

\footnotetext{
Received for publication 10 Dec. 2019. Accepted for publication 16 Mar. 2020.

Published online 14 May 2020.

Thanks to Brian Caldwell for help with field management and equipment usage in Freeville, NY. Thank you to Bejo Seeds for the donations of beet cv. Boro seeds for all of these experiments. Supported in part by USDA-NIFA OREI Program (2014-51300-22244), USDA-NIFA Hatch Project (1004501), and a Toward Sustainability Foundation Grant (2017).

A.R. is the corresponding author. E-mail: ar47@ cornell.edu.

This is an open access article distributed under the CC BY-NC-ND license (https://creativecommons. org/licenses/by-nc-nd/4.0/).
}

This research assessed the efficacy of using black plastic tarps to advance reduced-till systems by analyzing the effects of black tarps on the following: 1) the soil environment, including soil temperature, moisture, and inorganic nitrogen concentration; 2) weed seed survival; 3) surface cover crop residue before planting; and 4) weed percent cover before planting. We hypothesized that 1) tarps would improve the soil environment for no-till planting by increasing soil moisture, temperature, and inorganic nitrogen while decreasing crop residue, 2) tarps would promote fatal germination and decay of weed seeds, thus decreasing their survivability, 3) tarps would kill all emerged weeds, and 4) longer tarp durations would have greater effects on these soil conditions.

\section{Materials and Methods}

Field experiments were conducted at three locations in the northeastern United States (Freeville, NY; Monmouth, ME; Riverhead, NY) over 2 years (2017 and 2018). At each location, tarps were applied by hand for three durations before the target removal date (RD) (Table 1): 3 to 5 weeks (short), 6 to 8 weeks (mid), and 10 or more weeks (long). At two locations, Freeville, NY and Monmouth, $\mathrm{ME}$, the experiment was repeated for two removal dates each year (RD1 and RD2), with experiments adjacent to each other in the same field. An "experiment" refers to any individual field experiment within a location, year, and removal date, with a total of 10 experiments. The removal dates were selected based on targeted planting dates for a direct-seeded beet crop (Rylander et al., 2020). Each tarp duration was compared with an untarped control (none). All fields were disked and harrowed and seeded to an oat cover crop in August or September (based on location), and tarps were applied to untilled oat stands. All experiments used complete randomized block designs with four replications per treatment.

\section{Experimental design}

Freeville, NY. Research was conducted in a certified organic field at the Cornell University Homer C. Thompson Vegetable Research Farm in Freeville, NY (42.523204, -76.326472). Soils are a well-drained Howard gravelly loam (loamy-skeletal, mixed, active, mesic Glossic Hapludalfs). The field was seeded to oats at $112 \mathrm{~kg} \cdot \mathrm{ha}^{-1}$ on $25 \mathrm{Aug}$. 2016 and 2017. Oats were rotary-mowed (2017) or flail-mowed (2018) in midNovember, before winterkill, to chop cover crop residues before laying tarps. All plots were $3.7 \times 3.7 \mathrm{~m}$ with two beds that were $1.8 \mathrm{~m}$ from the center. Tarps were cut into 4.9- $\times 4.9-\mathrm{m}$ sections to cover plot edges and secured to the soil surface using sand bags without burying the edges.

Monmouth, ME. Research was conducted at the University of Maine Agricultural and Forestry Experiment Station: Highmoor Farm in Monmouth, ME (44.231993, -70.071939) in a noncertified but organically managed field. Soils are a Woodbridge fine sandy loam (coarse-loamy, mixed, active, mesic Aquic Dystrudepts). An oat cover crop was seeded in mid-Aug. 2016 and 2017 at $112 \mathrm{~kg} \cdot \mathrm{ha}^{-1}$ with a Great Plains drill (3P605NT; Great Plains, Salina, KS). In mid-December, oats were mechanically rolled down (2017) or flailmowed (2018). Plots were $3.0 \times 5.5 \mathrm{~m}$, encompassing three beds $1.8 \mathrm{~m}$ from the center. Tarps were held in place by sand bags and/or by burying the edges.

Riverhead, NY. Research was conducted in a noncertified but organically managed field at the Long Island Horticultural Research and Extension Center (LIHREC) in Riverhead, NY (40.962271, -72.716471). Soils are a Haven loam (coarse-loamy over sandy or sandy-skeletal, mixed, active, mesic Typic). A cover crop of oats $\left(89 \mathrm{~kg} \cdot \mathrm{ha}^{-1}\right)$ was seeded 9 Sept. 2016 and 26 Sept. 2017. Tarps were held in place by sand bags without burying the edges. Tarps were applied for only one removal date (Table 1).

\section{Sampling methods}

Soil temperature, moisture, and inorganic nitrogen. Soil temperature sensors (WatchDog B-Series Button Logger; Spectrum Technologies, Aurora, IL) were installed to a depth of $10 \mathrm{~cm}$ in the center of plots at the time when tarps were applied. Sensors recorded average daily soil temperatures until tarp removal. Average soil temperatures are reported for the day before tarp removal.

Gravimetric soil water content and soil inorganic nitrogen (nitrate and ammonium) were measured to a depth of $20 \mathrm{~cm}$ at the time of tarp removal both years and before tarp application in 2018. Soil cores (six per treatment) were composited, dried at $45{ }^{\circ} \mathrm{C}$, sieved to $2 \mathrm{~mm}$, and analyzed for nitrate-N and ammonium-N concentrations using $1 \mathrm{~N}$ $\mathrm{KCl}$ cadmium reduction (Dahnke, 1990) (Brookside Laboratories Inc., New Bremen, $\mathrm{OH})$.

Weed seed survival assessment. In Freeville, NY only, locally sourced seeds of Powell amaranth (Amaranthus powellii S. Wats.) and common lambsquarters (Chenopodium album L.) were collected in Fall 2017 to assess seed survival under tarps. One hundred seeds of one species were placed in a permeable fabric bag (Organza, S-10647; ULINE, Pleasant Prairie, WI) with $50 \mathrm{~g}$ of field soil sieved to $0.5 \mathrm{~mm}$. Seed bags were buried at a depth of $2.5 \mathrm{~cm}$ in a randomly chosen quadrant in the following treatments: untarped and short-duration tarp treatments for both removal dates and longduration tarp treatments for RD2. All bags were buried 28 Mar. 2018. Seeds were tested for germinability at $\approx 23{ }^{\circ} \mathrm{C}$ in light and moisture before the experiment. Germination rates were $65 \%$ and $43 \%$ for $A$. powellii and $C$. album, respectively. Seed survival was determined by gently pressing seeds with forceps to determine viability (Sawma and Mohler, 2002). Easily crushed seeds were determined to be unviable. Viability rates were $100 \%$ and $99 \%$ for $A$. powellii and C. album, respectively, before soil burial. 
Table 1. Tarp application and removal dates for Freeville, NY; Monmouth, ME; and Riverhead, NY for two target removal dates in 2017 and 2018 . Removal date one (RD1) and removal date two (RD2) indicate early vs. late-season tarp removal.

\begin{tabular}{|c|c|c|c|c|c|c|c|c|c|c|}
\hline & \multicolumn{4}{|c|}{ Freeville } & \multicolumn{4}{|c|}{ Monmouth } & & \\
\hline & \multicolumn{2}{|c|}{2017} & \multicolumn{2}{|c|}{2018} & \multicolumn{2}{|c|}{2017} & \multicolumn{2}{|c|}{2018} & \multicolumn{2}{|c|}{ Riverhead } \\
\hline & RD1 & RD2 & RD1 & RD2 & RD1 & RD2 & RD1 & RD2 & 2017 & 2018 \\
\hline Long-duration tarp applied & 15 Nov. & 30 Mar. & 17 Nov. & 2 Apr. & 8 Dec. & 27 Apr. & 21 Nov. & 10 Apr. & 19 Jan. & 21 Nov. \\
\hline Mid-duration tarp applied & 30 Mar. & 26 Apr. & 2 Apr. & 30 Apr. & 13 Apr. & 17 May & 13 Apr. & 21 May & 11 Apr. & 13 Apr. \\
\hline Short-duration tarp applied & 20 Apr. & 18 May & 23 Apr. & 21 May & 3 May & 9 June & 15 May & 11 June & 2 May & 4 May \\
\hline Tarps removed & 16 May & 16 June & 14 May & 11 June & 8 June & 6 July & 5 June & 11 July & 1 June & 29 May \\
\hline
\end{tabular}

Table 2. Soil temperature $\left({ }^{\circ} \mathrm{C}\right)$ at a 10 -cm depth the day before tarp removal for Freeville, NY and Monmouth, ME, separated by tarp removal date (RD1, RD2) and year.

\begin{tabular}{|c|c|c|c|c|c|}
\hline \multirow[b]{2}{*}{ Location } & \multirow[b]{2}{*}{ Tarp duration } & \multicolumn{2}{|c|}{2017} & \multicolumn{2}{|c|}{2018} \\
\hline & & $\mathrm{RD}^{\mathrm{z}}$ & $\mathrm{RD}^{\mathrm{y}}$ & $\mathrm{RD}^{\mathrm{x}}$ & $\mathrm{RD}^{\mathrm{w}}$ \\
\hline \multirow[t]{5}{*}{ Freeville } & None & $11.8 \mathrm{~b}^{\mathrm{v}}$ & $20.7 \mathrm{~b}$ & $15.6 \mathrm{~b}$ & $18.6 \mathrm{~b}$ \\
\hline & Short & $13.2 \mathrm{a}$ & $21.3 \mathrm{ab}$ & $15.8 \mathrm{ab}$ & $20.4 \mathrm{a}$ \\
\hline & Mid & $13.3 \mathrm{a}$ & $21.4 \mathrm{a}$ & $16.1 \mathrm{ab}$ & $20.7 \mathrm{a}$ \\
\hline & Long & $13.3 \mathrm{a}$ & $21.6 \mathrm{a}$ & $16.4 \mathrm{a}$ & $20.9 \mathrm{a}$ \\
\hline & & ** & * & * & $* * *$ \\
\hline \multirow[t]{5}{*}{ Monmouth } & None & $19.1 \mathrm{~b}$ & 24.1 & $15.8 \mathrm{~b}$ & $22.9 \mathrm{~b}$ \\
\hline & Short & $20.8 \mathrm{a}$ & 25.6 & $17.1 \mathrm{a}$ & $28.0 \mathrm{a}$ \\
\hline & Mid & $20.1 \mathrm{ab}$ & 25.5 & $17.1 \mathrm{a}$ & $28.7 \mathrm{a}$ \\
\hline & Long & $20.4 \mathrm{ab}$ & 25.0 & $16.8 \mathrm{a}$ & $27.4 \mathrm{a}$ \\
\hline & & $*$ & NS & $* * *$ & $* * *$ \\
\hline
\end{tabular}

${ }^{\mathrm{z}}$ Data from Freeville: 15 May 2017, Monmouth: 7 June 2017

${ }^{\mathrm{y}}$ Data from Freeville: 15 June 2017, Monmouth: 5 July 2017

${ }^{\mathrm{x}}$ Data from Freeville: 13 May 2018, Monmouth: 4 June 2018

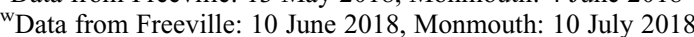

'Mean separation by Tukey's honestly significant difference test at $P \leq 0.05$.

Ns, *,**,**Nonsignificant or significant at $P \leq 0.05,0.01$, or 0.001 , respectively.

On tarp removal, all seed bags were removed from the field, dried at $45{ }^{\circ} \mathrm{C}$ for $48 \mathrm{~h}$, and sieved through a $0.5-\mathrm{mm}$ sieve to separate weed seeds from soil. Intact weed seeds were tested for viability. The proportion of surviving seeds remaining in the bags relative to the total number of initial seeds (100) was then determined. Differences between the numbers of initial and final viable seeds were used to calculate losses from fatal germination or seed decay.

Cover crop residue and weed percent cover. The percent of cover crop residue and weed presence in plots was determined using a beaded string method (Shelton and Jasa, 2009). Beads were spaced at a $33-\mathrm{cm}$ interval on a $5-\mathrm{m}$ string ( 15 beads per $5 \mathrm{~m}$ ). The string was laid across the plot in two directions; the presence/absence of crop residue and the presence/absence of weeds were recorded under each bead (total of 30 measures per plot). Data were converted to percent residue or percent weed cover.

Precipitation. Daily rainfall and temperature data were collected and summarized from weather stations in Freeville, NY and Riverhead, NY (Network for Environment and Weather Applications, 2018), and from an on-farm station in Monmouth, $\mathrm{ME}$ (HOBO U30; Onset Computer Corporation, Bourne, MA).

Statistical analysis. Least-squares means were compared using analysis of variance (ANOVA) using R (R Core Team, 2017) with tarp duration as a fixed effect within the randomized complete block design. Figures were produced using ggplot 2 (Wickham,
2016). Mean separation was performed using the Tukey-Kramer honestly significant difference (HSD) test at $P=0.05$. Before performing the ANOVA regression, data were checked for normality of residuals to meet the assumptions of the ANOVA. Data for each location and tarp removal date were analyzed separately, due to variance in management methods and significance of the site to the statistical results, to facilitate comparisons of experiment-specific data across soils, weeds, and crop yields (Rylander et al., 2020).

\section{Results}

Soil temperature, moisture, and inorganic nitrogen. Tarp use significantly increased soil temperatures at the time of tarp removal compared with untarped treatments $(P<$ $0.05)$ in most locations, removal dates, and years (Table 2). At the time of tarp removal, there was no significant difference among short, medium, and long tarp treatments. Soil temperatures under tarps averaged 1 to $3{ }^{\circ} \mathrm{C}$ higher than those of untarped treatments. In Monmouth 2018 RD2, tarps increased the soil temperature 4.5 to $5.8^{\circ} \mathrm{C}$. The highest average temperature achieved under tarps was $28.7^{\circ} \mathrm{C}$ in Monmouth $2018 \mathrm{RD} 2$. There was a positive correlation between soil moisture and temperature at the time of removal in 3 of 10 experiments $(P<0.05)$ and a similar trend in two other experiments $(P<0.1)$.

Differences in tarp duration did not affect soil moisture; therefore, data are presented for tarped vs. untarped treatments. Ambient precipitation during the months before tarp removal (April to May through July, depending on the removal date and site) varied by site and year (data not shown), and there was no correlation between cumulative precipitation during tarp duration and soil moisture at the time of tarp removal. Soil moisture under tarps at the time of removal was similar to or greater than that of untarped soil (Table 3). Tarps increased soil moisture in five of the experiments, ranging from $10 \%$ to $55 \%$ greater under tarps compared with the untarped treatments. In Freeville and Monmouth, there was a consistent effect for both removal dates in 2018. There was no moisture effect at the Riverhead location in either year.

Tarp use of any duration increased soil nitrate $\left(\mathrm{NO}_{3}-\mathrm{N}\right)$ concentrations compared with untarped treatments (Fig. 1). In Freeville, soil nitrate concentrations ranged from 2 to $31 \mathrm{mg} \cdot \mathrm{kg}^{-1}$ dry soil and were 4 - to 14 times higher after tarping in $2017(P<0.001)$, and they ranged from 2 to $22 \mathrm{mg} \cdot \mathrm{kg}^{-1}$ dry soil and were 3 - to 11-times higher after tarping in $2018(P<0.001)$. In Monmouth, nitrate concentrations ranged from 2 to $36 \mathrm{mg} \cdot \mathrm{kg}^{-1}$ dry soil and were 1-time to 18-times higher after tarping for RD1 in $2017(P<0.001)$, and they ranged from 2 to $42 \mathrm{mg} \cdot \mathrm{kg}^{-1}$ dry soil and were 8- to 21-times higher in 2018 ( $P<$ 0.001). In Riverhead, similar trends of significantly higher soil nitrate concentrations in $2017(P<0.001)$ and $2018(P<0.001)$ were observed. Only one application time (RD1 in Monmouth in 2017) had similar nitrate concentrations among tarped and untarped treatments.

Soil nitrate concentrations significantly increased with longer tarp duration in all locations, removal dates, and years except RD1 2017 in Maine $(P<0.05)$ (Fig. 1). Pretarp nitrate concentrations were not different among tarped and untarped treatments in 2018 , averaging $3 \mathrm{mg} \cdot \mathrm{kg}^{-1}$ dry soil $(\mathrm{SE}=$ 0.3 ) in Freeville and $4 \mathrm{mg} \cdot \mathrm{kg}^{-1}$ dry soil (SD = 0.5 ) in Monmouth (Riverhead not sampled). Soil ammonium was unaffected by tarps except for RD2 in 2017 in Monmouth, where it decreased from $11 \mathrm{mg} \cdot \mathrm{kg}^{-1}$ without tarp use to an average of $7 \mathrm{mg} \cdot \mathrm{kg}^{-1}$ dry soil with tarp use $(P<0.01)$ (data not shown).

Weed seed survival. Tarping had no consistent impact on seed survival of $A$. powellii seeds. The proportion of surviving seeds by the end of the tarping period was significantly greater under short-duration tarps $(82 \%)$ relative to untarped treatments $(73 \%)$ for RD1 but not RD2 $(P<0.05)$ (data not shown). 
Table 3. Gravimetric soil moisture (\%) in the top $20 \mathrm{~cm}$ of soil in tarped and untarped plots in Freeville, NY; Monmouth, ME; and Riverhead, NY on different tarp removal dates (RD1, RD2).

\begin{tabular}{|c|c|c|c|c|c|}
\hline \multirow[b]{2}{*}{ Location } & \multirow[b]{2}{*}{ Treatment } & \multicolumn{2}{|c|}{2017} & \multicolumn{2}{|c|}{2018} \\
\hline & & $\overline{\mathrm{RD} 1^{2}}$ & $\mathrm{RD}^{\mathrm{y}}$ & $\overline{R D 1^{x}}$ & $\mathrm{RD}^{2}$ \\
\hline \multirow[t]{3}{*}{ Freeville } & Untarped & 20.3 & 21.8 & 22.8 & 21.0 \\
\hline & Tarped & 21.3 & 22.6 & 26.8 & 27.3 \\
\hline & & $\mathrm{NS}^{\mathrm{v}}$ & NS & $*$ & $* *$ \\
\hline \multirow[t]{3}{*}{ Monmouth } & Untarped & 30.5 & 31.4 & 17.1 & 17.1 \\
\hline & Tarped & 33.4 & 36.2 & 24.4 & 26.5 \\
\hline & & $* *$ & NS & $*$ & $* * *$ \\
\hline \multirow[t]{3}{*}{ Riverhead } & Untarped & 16.3 & - & 10.7 & - \\
\hline & Tarped & 16.3 & - & 11.0 & - \\
\hline & & NS & - & NS & - \\
\hline
\end{tabular}

${ }^{\mathrm{z}}$ Tarps removed in Freeville: 16 May 2017; Monmouth: 8 June 2017; Riverhead: 1 June 2017.

${ }^{\mathrm{y}}$ Tarps removed in Freeville: 16 June 2017; Monmouth: 6 July 2017; Riverhead had only one tarp removal date.

${ }^{\mathrm{x}}$ Tarps removed in Freeville: 14 May 2018; Monmouth: 5 June 2018; Riverhead: 29 May 2018.

${ }^{\text {w}}$ Tarps removed in Freeville: 11 June 2018; Monmouth: 11 July 2018; Riverhead had only one tarp removal date

${ }^{\vee}$ Mean separation by Tukey's honestly significant difference test at $P \leq 0.05$.

Ns, ${ }^{*}, * * * *$ Nonsignificant or significant at $P \leq 0.05,0.01$, or 0.001 , respectively.

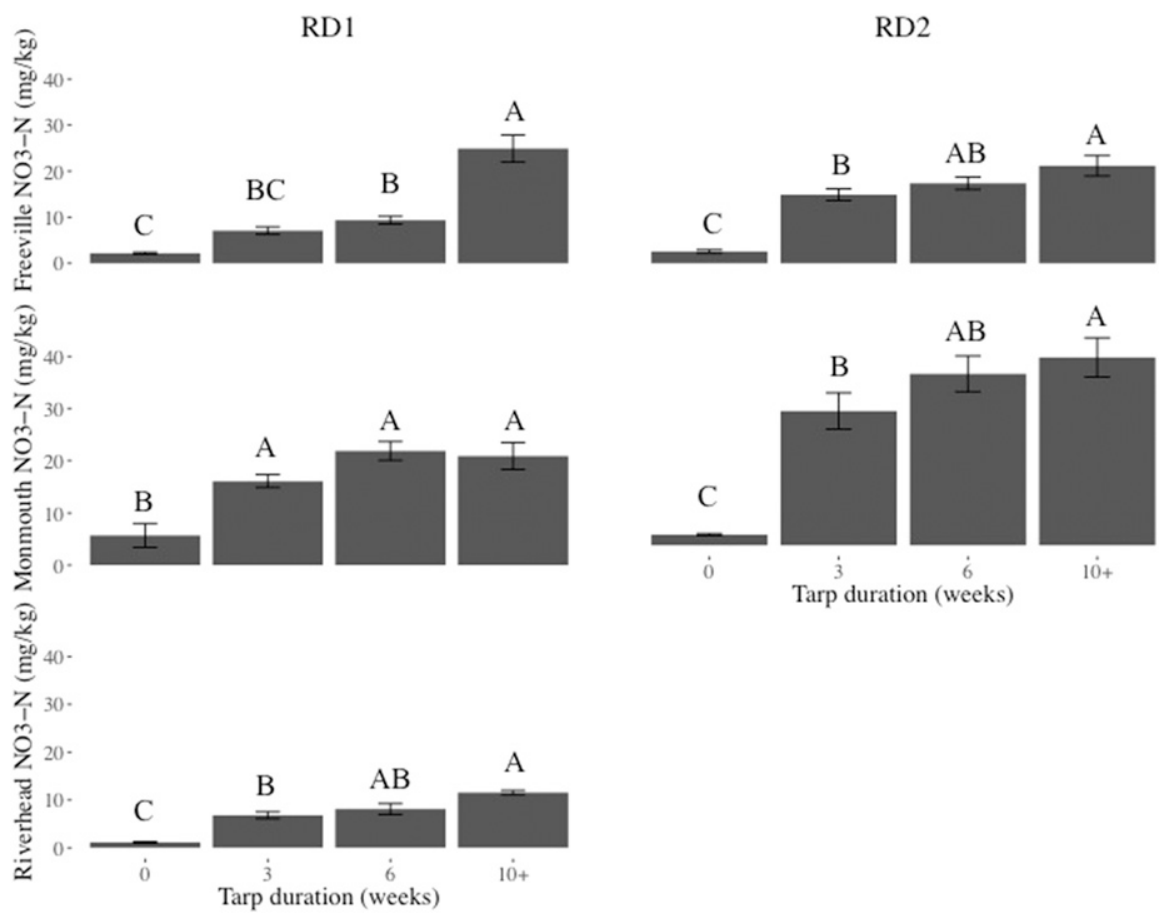

Fig. 1. Soil $\mathrm{NO}_{3}-\mathrm{N}$ concentrations $\left(\mathrm{mg} \cdot \mathrm{kg}^{-1}\right)$ posttarp in the top $20 \mathrm{~cm}$ of soil in Freeville, NY; Monmouth, ME; and Riverhead, NY combined over 2 years (2017 and 2018) and separated by tarp removal dates (RD1, RD2). Riverhead had only one tarp removal date.

Tarps had no effect on C. album seed survival, which averaged $86 \%$.

Cover crop residue and weed percent cover. The percent of soil covered by cover crop residue at the time of tarp removal was similar between tarped and untarped treatments for RD1 at Freeville and Monmouth both years. In 2018, the percent residue cover at RD2 was $20 \%$ to $30 \%$ higher $(P<0.05)$ after tarping compared with untarped treatments in Freeville, and two- to three-times higher $(P<0.05)$ in Riverhead (Table 4$)$. In Monmouth, the percent residue cover was one- to three-times higher $(P<0.05)$ under ing tarps to achieve typical tillage benefits, such as soil warming and drying, increased soil nitrogen availability, early-season weed control, and cover crop residue decomposition. Tarp use increased soil temperature and moisture under certain conditions, increased soil nitrate concentrations, and reduced earlyseason weeds relative to untarped treatments. Cover crop residue, however, was not reduced by tarping, which could interfere with crop planting without specialized approaches or equipment for managing high-residue situations.

Short-duration tarps were generally as effective as longer-duration tarps for most parameters. Only soil nitrate concentrations increased with longer-duration tarps. These findings are promising because short-duration tarping provides farmers with more flexibility before and between plantings.

The average soil temperature under tarps was 1 to $3{ }^{\circ} \mathrm{C}$ higher than that of untarped treatments when tarps were applied later in the season. This observation was consistent with the 1 to $6{ }^{\circ} \mathrm{C}$ increase in the average soil temperature under black tarps reported in Maine, where tarps were applied over bare soil (Birthisel, 2018), but it was in contrast to results from New Hampshire, where tarps were applied over a cover crop mulch and temperatures decreased under black tarps in June compared with untarped treatments (Lounsbury et al., 2018).

Mid-season use of clear plastic for solarization and full-season black mulch films both increase soil temperature more than that observed with tarps (Abu-Gharbieh et al., 1988; Canul-Tun et al., 2017; Filipovic et al., 2016; Öz, 2018; Ramakrishna et al., 2006). The application of tarps during times with cool ambient air temperatures could limit possible soil warming. Black plastic films absorb shortwave radiation from the sun and transfer that heat to the soil through thermal conductivity (Ham et al., 1993; Ham and Kluitenberg, 1994); therefore, plastic-to-soil contact is vital to facilitate heat transfer (Liakatas et al., 1986). Cover crop residue or uneven ground under tarps could affect the soil temperature gain given the separation of the tarp from the soil surface. Greater tarp contact with the soil surface, the tightness of tarps over formed beds, and/or different methods of securing tarp edges could also contribute to the degree of soil warming by tarps.

Soil moisture and rainfall events during tarping may also affect soil temperatures under tarps compared with untarped treatments. High soil moisture can increase soil temperature by improving soil heat storage capacity (Al-Kayssl et al., 1990). The positive correlation between soil moisture and temperature observed at tarp removal suggests that tarps may increase soil temperatures by increasing soil moisture. Previous studies have found greater stability of soil moisture under black tarps compared with moisture in bare soil, which fluctuated drastically with rain events (Lounsbury et al., 2018). By keeping soil moist in dry ambient 
Table 4. Surface residue percent cover at tarp removal for Freeville, NY; Monmouth, ME; and Riverhead, NY by tarp removal date (RD1, RD2) and year.

\begin{tabular}{|c|c|c|c|c|c|}
\hline \multirow[b]{2}{*}{ Location } & \multirow[b]{2}{*}{ Tarp duration } & \multicolumn{2}{|c|}{2017} & \multicolumn{2}{|c|}{2018} \\
\hline & & RD1 & RD2 & RD1 & RD2 \\
\hline \multirow[t]{5}{*}{ Freeville } & None & 65 & 54 & 79 & $51 b^{2}$ \\
\hline & Short & 59 & 58 & 81 & $65 \mathrm{a}$ \\
\hline & Mid & 62 & 53 & 78 & $67 \mathrm{a}$ \\
\hline & Long & 77 & 60 & 80 & $61 \mathrm{al}$ \\
\hline & & NS & NS & NS & $*$ \\
\hline \multirow[t]{5}{*}{ Monmouth } & None & 78 & $44 \mathrm{~b}$ & 91 & $30 \mathrm{~b}$ \\
\hline & Short & 70 & $86 \mathrm{a}$ & 80 & $92 \mathrm{a}$ \\
\hline & Mid & 71 & $80 \mathrm{a}$ & 77 & $75 \mathrm{a}$ \\
\hline & Long & 74 & $67 \mathrm{a}$ & 88 & $77 \mathrm{a}$ \\
\hline & & NS & $*$ & NS & $* * *$ \\
\hline \multirow[t]{5}{*}{ Riverhead } & None & $78 \mathrm{ab}$ & - & $6 \mathrm{c}$ & - \\
\hline & Short & $68 \mathrm{~b}$ & - & $12 \mathrm{~b}$ & 一 \\
\hline & Mid & $77 \mathrm{ab}$ & - & $15 \mathrm{ab}$ & - \\
\hline & Long & $79 \mathrm{a}$ & - & $16 \mathrm{a}$ & - \\
\hline & & $*$ & - & $* * *$ & - \\
\hline
\end{tabular}

${ }^{\mathrm{z}}$ Mean separation by Tukey's honestly significant difference at $P \leq 0.05$.

NS, *,**,***Nonsignificant or significant at $P \leq 0.05,0.01$, or 0.001 respectively.

Table 5. Effects of tarp duration on weed percent cover for two tarp removal dates (RD1 and RD2) in 2017 and 2018 at Freeville, NY; Monmouth, ME; and Riverhead, NY.

\begin{tabular}{|c|c|c|c|c|c|c|c|c|c|}
\hline \multirow[b]{3}{*}{ Tarp duration } & \multicolumn{4}{|c|}{ Freeville } & \multicolumn{4}{|c|}{ Monmouth } & \multirow{3}{*}{$\frac{\text { Riverhead }}{2018}$} \\
\hline & \multicolumn{2}{|c|}{2017} & \multicolumn{2}{|c|}{2018} & \multicolumn{2}{|c|}{2017} & \multicolumn{2}{|c|}{2018} & \\
\hline & $\overline{\mathrm{RD} 1}$ & $\overline{\mathrm{RD} 2}$ & $\overline{\mathrm{RD} 1}$ & $\overline{\mathrm{RD} 2}$ & $\overline{\mathrm{RD} 1}$ & $\overline{\mathrm{RD} 2}$ & $\overline{\mathrm{RD} 1}$ & RD2 & \\
\hline None & $12 \mathrm{a}^{\mathrm{z}}$ & $59 a$ & $64 a$ & $95 \mathrm{a}$ & $33 a$ & $98 \mathrm{a}$ & $86 a$ & $100 \mathrm{a}$ & $7 \mathrm{a}$ \\
\hline Short & $0 \mathrm{~b}$ & $0 \mathrm{~b}$ & $1 \mathrm{~b}$ & $0 \mathrm{~b}$ & $0 \mathrm{~b}$ & $5 \mathrm{~b}$ & $4 \mathrm{~b}$ & $4 \mathrm{~b}$ & $0 \mathrm{~b}$ \\
\hline Mid & $0 \mathrm{~b}$ & $0 \mathrm{~b}$ & $0 \mathrm{~b}$ & $0 \mathrm{~b}$ & $0 \mathrm{~b}$ & $2 \mathrm{~b}$ & $3 \mathrm{~b}$ & $3 \mathrm{~b}$ & $0 \mathrm{~b}$ \\
\hline \multirow[t]{2}{*}{ Long } & $0 \mathrm{~b}$ & $0 \mathrm{~b}$ & $0 \mathrm{~b}$ & $0 \mathrm{~b}$ & $0 \mathrm{~b}$ & $2 b$ & $3 b$ & $3 \mathrm{~b}$ & $0 \mathrm{~b}$ \\
\hline & $* * *$ & $* * *$ & $* * *$ & $* * *$ & $* * *$ & $* * *$ & $* * *$ & $* * *$ & $* * *$ \\
\hline
\end{tabular}

${ }^{\mathrm{z}}$ Mean separation by Tukey's honestly significant difference test at $P \leq 0.05$.

NS, ${ }^{*}, * *, * * *$ Nonsignificant or significant at $P \leq 0.05,0.01$, or 0.001 , respectively.

conditions and limiting rainfall contact and waterlogging of poorly drained soils in heavy rain events, tarps may facilitate earlier planting compared with bare ground in wet springs.

The soil nitrate concentration increased by up to $40 \mathrm{mg} \cdot \mathrm{kg}^{-1}$ with long-duration tarp use without any pre-plant tillage. In other experiments, plastic mulch film increased nitrate concentrations in the soil (Teasdale and Mohler, 2000), but this was measured during the cropping season after tillage. Nitrate is a highly soluble and easily leached compound. Tarps likely reduce nitrate leaching losses by rainfall. Longer tarp durations protect the soil from rainfall for a longer period, allowing more nitrate to remain in the soil from the time of tarp application. It is also possible that tarps prevent waterlogging in poorly drained soils following heavy rain events, thereby decreasing the risk of anaerobic conditions and denitrification. Nitrate uptake by weeds in untarped soils could have also reduced soil nitrate relative to tarped soils. Weed percent cover in uncovered plots at the time of tarp removal was greater than $50 \%$ in 6 out of 10 experiments, mainly in RD2.

Increased soil temperature and moisture under tarps may also promote microbial activity, thus increasing the rate of nitrification in the soil. Soil microbes respond favorably to increased soil moisture and temperature
(Brockett et al., 2012) and less variable soil conditions (Biederbeck and Campbell, 1973). Soil moisture and temperature fluctuated less under black tarps compared with untarped treatments in New Hampshire (Lounsbury et al., 2018). In 4 out of 10 experiments, there was a significant correlation between increased soil moisture and increased nitrate concentrations at the time of tarp removal $(P<0.05)$, but there was no consistent correlation between nitrate concentrations and soil temperature at the time of tarp removal. These results suggest that moisture dynamics under tarps may influence nitrate concentrations in the soil by increasing microbial activity and nitrification. Further studies are needed to verify mechanisms for nitrate increase with tarping.

In these experiments, tarps did not reduce cover crop residue. This is in contrast to the observations of black tarps decreasing rollercrimped cereal rye/hairy vetch cover crop residue biomass compared with untarped treatments in New Hampshire (Lounsbury et al., 2018). In that study, the observed degradation of cover crop residue was attributed to less soil temperature and moisture fluctuations, creating a more stable environment for soil microbes.

Although the increased moisture and temperatures under tarps may promote microbial activity, cover crop residue in these experiments was not incorporated into the soil.
Decreased exposure to rainfall, wind, and sunlight under tarps may have slowed the degradation of oat cover crop residue compared with untarped treatments in these experiments. Farmers have generally observed an increase in cover crop residue degradation with tarp application when preceded by tillage or compost application (personal communication). In our trials, tarps were applied directly over flail-mowed oat residue with no soil incorporation or organic amendments applied before tarp application. Tilling before tarp application would bury crop residue and potentially increase contact with soil microbes responsible for residue degradation (Zheng et al., 2018).

Tarps did not have a clear impact on weed seed viability, as measured by the number of seeds that did not germinate or decay in the soil. Seed predation could not be measured with the mesh bag method used in this study. The number of surviving $A$. powellii seeds was higher under some tarp treatments relative to untarped treatments, indicating that fewer seeds germinated or decayed in the soil. Other studies reported increases in redroot pigweed (Amaranthus retroflexus L.) seed germination in the absence of light when nitrate concentrations and temperatures increase $\left(20^{\circ} \mathrm{C}\right)$ (Gallagher and Cardina, 1998; Teasdale and Mohler, 2000). Despite increased soil nitrate concentrations and temperatures under tarps, $A$. powellii seed germination and decay did not increase under tarps compared with bare ground. The survival of C. album seeds was unaffected by tarping, suggesting that tarps do not influence the germination and decay of seeds in this species. Chenopodium album germination does not respond drastically to nitrate concentrations (Saini et al., 1985), and it often shows an inconsistent emergence response to changing environmental cues caused by operations such as tillage (Chauhan and Johnson, 2010).

Tarp use for 3 weeks was sufficient to kill almost all emerged weeds present at the time of tarp application and leave untilled soil free of living weeds, consistent with data collected from New Hampshire and Maine (Birthisel, 2018; Lounsbury et al., 2018). Stellaria media L. was the most common weed species in untarped plots, and it was dead or absent in tarped plots. White thread-stage weed seedlings were observed under short-duration tarps for 2018 RD1 in Freeville, but these weed seedlings died within several hours of tarp removal. Suppressing weeds early in the season could give crops a temporal competitive advantage over weeds during a critical period of growth (Chaudhari et al., 2016; Safdar et al., 2016).

\section{Conclusions}

Tarps may be an effective strategy to facilitate reduced-till approaches in organic vegetable systems by increasing soil temperatures and nitrate concentrations, and by creating a weed-free environment before planting a crop. Nitrate concentrations increased dramatically with longer tarp durations, reaching average concentrations of up 
to $42 \mathrm{mg} \cdot \mathrm{kg}^{-1}$ compared with bare ground concentrations of $2 \mathrm{mg} \cdot \mathrm{kg}^{-1}$, but the mechanisms for this are unclear. Tarps did not affect cover crop residue on the soil surface, and residue interference poses a significant challenge in reduced-till systems. Crop residue degradation likely depends on the cover crop used, the method of termination, the type of soil disturbance or tillage before tarping, amendments applied, and climatic conditions. Tarp impacts on weed seed germination and decay remain unclear. Weed seed dynamics under tarps likely depend on complex conditions and interactions varying with the time of tarp use and the species present. Further studies are needed to understand 1) mechanisms for nitrate accumulations under tarps, 2) how different cover crops and residue management before tarping influence decomposition under tarps, and 3) how tarp timing and duration reduce specific weed species in the soil seed bank.

Although soil nitrate concentrations benefit from longer tarp durations, 3 weeks was sufficient time for tarps to provide a seedbed, with weeds reduced by $95 \%$ to $100 \%$ compared with uncovered ground. These soil impacts contribute to an improved seedbed for planting without tillage. On intensively managed farms, shorter tarp durations (as opposed to longer durations) provide farmers with more temporal flexibility to use tarps before or between plantings. Tarping provides farmers with a new strategy to manage weeds and facilitate reduced tillage in organic vegetable systems.

\section{Literature Cited}

Abu-Gharbieh, W.I., H. Saleh, and H. Abu-Blan. 1988. Use of black plastic for soil solarization and post-plant mulching. FAO Plant Production and Protection Paper 109. Plant Protection Dept., Faculty of Ag., Univ. of Jordan, Amman, Jordan.

Al-Kayssl, A.W., A.A. Al-Karaghouli, A.M. Hasson, and S.A. Beker. 1990. Influence of soil moisture content on soil temperature and heat storage under greenhouse conditions. J. Agr. Eng Res. 45:241-252.

Alliaume, F., W.A.H. Rossing, P. Tittonell, and S. Dogliotti. 2017. Modeling soil tillage and mulching effects on soil water dynamics in raised-bed vegetable rotations. Eur. J. Agron. 82(January):268-281.

Biederbeck, V.O. and C.A. Campbell. 1973. Soil microbial activity as influenced by temperature trends and fluctuations. Can. J. Soil Sci. 53:363-376.

Birthisel, S.K. 2018. Multi-tactic ecological weed management in a changing climate. Univ. of Maine, Orono, PhD Diss. 2928.

Brockett, B.F.T., C.E. Prescott, and S.J. Grayston. 2012. Soil moisture is the major factor influencing microbial community structure and enzyme activities across seven biogeoclimatic zones in Western Canada. Soil Biol. Biochem. 44:9-20.

Candido, V., D. Castronuovo, V. Miccolis, and T. D'Addabbo. 2011. Weed control and yield response of soil solarization with different plastic films in lettuce. Scientia Hort. 130:491-497.

Canul-Tun, C.E., L. Ibarra-Jimenez, L.A. ValdezAguilar, A.J. Lozano-del Rio, A. Cardenas-Flores,
A. Zermeno-Gonzalez, C.J. Lozano-Cavazos, J.H. Valenzuela-Soto, and V. Torres-Olivar. 2017. Influence of colored plastic mulch on soil temperature, growth, nutrimental status, and yield of bell pepper under shade house conditions. J. Plant Nutr. 40(8):1083-1090.

Chaudhari, S., S.J. McGowen, F.J. Louws, K.M. Jennings, D.W. Monks, D.L. Jordan, and C.C. Gunter. 2016. Critical period for weed control in grafted and nongrafted fresh market tomato. Weed Sci. 64:523-530.

Chauhan, B.S., G.S. Gill, and C. Preston. 2006 Tillage system effects on weed ecology, herbicide activity and persistence: A review. Austral. J. Expt. Agr. 46:1557-1570.

Chauhan, B.S. and D.E. Johnson. 2010. The role of seed ecology in improving weed management strategies in the tropics. Adv. Agron. 105:221262.

Chauhan, B.S., R.G. Singh, and G. Mahajan. 2012. Ecology and management of weeds under conservation agriculture: A review. Crop Prot. 38:57-65.

Clements, D.R., D.L. Benott, S.D. Murphy, D.L. Benoit, and C.J. Swanton. 1996. Tillage effects on weed seed return and seedbank composition. Weed Sci. 44(2):314-322.

Dahnke, W.C. 1990. Testing soils for available nitrogen, p. 120-140. In: R.L. Westerman (ed.). Soil testing and plant analysis. Soil Sci. Soc. Am. Book Series 3, ASA, Madison, WI.

Egley, G.H. 1983. Weed seed and seedling reductions by soil solarization with transparent polyethylene. Weed Sci. 31:404-409.

Fan, Y., L. Tong, R. Ding, S. Kang, S. Li, T. Du, and X. Hao. 2017. Plastic mulch decreases available energy and evapotranspiration and improves yield and water use efficiency in an irrigated maize cropland. Agr. Water Mgt. 179:122-131.

Filipovic, V., D. Romic, M. Romic, J. Borosic, L. Filipovic, F.J.K. Mallmann, and D.A. Robinson. 2016. Plastic mulch and nitrogen fertigation in growing vegetables modify soil temperature, water and nitrate dynamics: Experimental results and a modeling study. Agr. Water Mgt. 176:100-110.

Franzluebbers, A.J. 2002. Water infiltration and soil structure related to organic matter and its stratification with depth. Soil Tillage Res. 66:197-205.

Fritz, V.A. 2012. Plastic mulches: Benefits, types, and sources. Minnesota high tunnel production manual for commercial growers. 2nd ed. Univ. Minn.

Gallagher, R.S. and J. Cardina. 1998. Phytochromemediated amaranthus germination. II. Development of very low fluence sensitivity. Weed Sci. 46(1):53-58.

Gu, Y.-J., C.-L. Han, J.-W. Fan, X.-P. Shi, M Kong, X.-Y. Shi, K.H.M. Siddique, Y.-Y. Zhao, and F.-M. Li. 2018. Alfalfa forage yield, soil water and $\mathrm{P}$ availability in response to plastic film mulch and $\mathrm{P}$ fertilization in a semiarid environment. Field Crops Res. 215:94-103.

Ham, J.M., G.J. Kluitenberg, and W.J. Lamont. 1993. Optical properties of plastic mulches affect the field temperature regime. J. Amer. Soc. Hort. Sci. 118:188-193.

Ham, J.M. and G.J. Kluitenberg. 1994. Modeling the effect of mulch optical properties and mulch-soil contact resistance on soil heating under plastic mulch culture. J. Agr. Forest Meteorol. 71:403-424.

Hungria, M., J.C. Franchini, O. Brandão-Junior, G. Kaschuk, and R.A. Souza. 2009. Soil microbial activity and crop sustainability in a long-term experiment with three soil-tillage and two croprotation systems. Appl. Soil Ecol. 42(3):288296.

Kanaan, H., S. Frenk, M. Raviv, S. Medina, and D. Minz. 2018. Long and short term effects of solarization on soil microbiome and agricultural production. Appl. Soil Ecol. 124:54-61.

Kasirajan, S. and M. Ngouajio. 2012. Polyethylene and biodegradable mulches for agricultural applications: A review. Agron. Sustain. Dev. 32:501-529.

Khan, M.A., R. Khan, H. Khan, H.U. Shah, K.B. Marwat, A. Amin, and A. Nawaz. 2012. Soil solarization: An organic weed-management approach in cauliflower. Commun. Soil Sci. Plant Anal. 43(13):1847-1860.

Laufer, D., B. Loibl, B. Märländer, and H.J. Koch. 2016. Soil erosion and surface runoff under strip tillage for sugar beet (Beta vulgaris L.) in Central Europe. Soil Tillage Res. 162:1-7.

Liakatas, A., J.A. Clark, and J.L. Monteith. 1986. Measurements of the heat balance under plastic mulches. Part I. Radiation balance and soil heat flux. Agr. For. Meteorol. 36:227-239.

Linke, K.H. 1994. Effects of soil solarization on arable weeds under Mediterranean conditions: Control, lack of response or stimulation. Crop Prot. 13(2):115-120.

Lounsbury, N.P., N.D. Warren, S.D. Wolfe, and R.G. Smith. 2018. Investigating tarps to facilitate organic no-till cabbage production with high-residue cover crops. Renewable Ag. Food Systems. p. 1-7.

Lowry, C.J. and D.C. Brainard. 2017. Organic farmer perceptions of reduced tillage: A Michigan farmer survey. Renew. Agr. Food Syst. 34(2):103-115.

Lu, J., Z. Bai, G.L. Velthof, Z. Wu, D. Chadwick, and L. Ma. 2019. Accumulation and leaching of nitrate in soils in wheat-maize production in China. Agr. Water Mgt. 212(February):407415.

Nakamoto, T., J. Yamagishi, and F. Miura. 2006. Effect of reduced tillage on weeds and soil organisms in winter wheat and summer maize cropping on humic andosols in central Japan. Soil Tillage Res. 85(1-2):94-106.

Network for Environment and Weather Applications. 2018. <http://Newa.cornell.edu/>.

Öz, H. 2018. A new approach to soil solarization: Addition of biochar to the effect of soil temperature and quality and yield parameters of lettuce (Lactuca sativa L. Duna). Scientia Hort. 228:153-161.

R Core Team. 2017. R: A language and environment for statistical computing. R Foundation for Statistical Computing, Vienna, Austria. $<$ https://R-project.org/>.

Ramakrishna, A., H.M. Tam, S.P. Wani, and T.D. Long. 2006. Effect of mulch on soil temperature, moisture, weed infestation and yield of groundnut in northern Vietnam. Field Crops Res. 95:115-125.

Raoufat, M.H. and R.A. Mahmoodieh. 2005. Stand establishment responses of maize to seedbed residue, seed drill coulters and primary tillage systems. Biosyst. Eng. 90(3):261-269.

Rylander, H.R., A. Rangarajan, R.M. Maher, M.G. Hutton, N.W. Rowley, M.T. McGrath, and Z.F. Sexton. 2020. Black plastic tarps advance organic reduced tillage II: Impacts on weeds and beet yield. HortScience 55:826-831.

Safdar, M.E., A. Tanveer, A. Khaliq, and R. Maqbool. 2016. Critical competition period of parthenium weed (Parthenium hysterophorus L.) in maize. Crop Prot. 80:101-107.

Saini, H.S., P.K. Bassi, and M.S. Spencer. 1985. Seed germination in Chenopodium album L: 
Relationships between nitrate and the effects of plant hormones. Plant Physiol. 77:940-943.

Samtani, J.B., J. Derr, M.A. Conway, and R.D. Flanagan, III. 2017. Evaluating soil solarization for weed control and strawberry (Fragaria xananassa) yield in annual plasticulture production. Weed Technol. 31:455-463.

Sawma, J.T. and C.L. Mohler. 2002. Evaluating seed viability by an unimbibed seed crush test in comparison with the tetrazolium test. Weed Technol. 16(4):781-786.

Shelton, D.P. and P.J. Jasa. 2009. Estimating percent residue cover using the line-transect method. NebGuide. University of Nebraska, Lincoln. $<$ http://extensionpublications.unl.edu/ assets/pdf/g1931.pdf>.

Teasdale, J.R. and C.L. Mohler. 2000. The quantitative relationship between weed emergence and the physical properties of mulches. Weed Sci. 48(3):385-392.

Tebrügge, F. and R.A. Düring. 1999. Reducing tillage intensity - a review of results from a long-term study in Germany. Soil Tillage Res. 53:15-28.

TerArvest, D., L. Carpenter-Boggs, C. Thierfelder, and J.P. Reganold. 2015. Crop production and soil water management in conservation agriculture, no-till, and conventional tillage systems in Malawi. Agr. Ecosyst. Environ. 212:285-296.

Want, J., H. Zhang, X. Li, Z. Su, X. Li, and M. Xu. 2014. Effects of tillage and residue incorporation on composition and abundance of microbial communities of a fluvo-aquic soil. Eur. J. Soil Biol. 65:70-78.

Wickham, H. 2016. ggplot2: Elegant graphics for data analysis. Springer-Verlag, New York.
Yu, Y.Y., N.C. Turner, Y.H. Gong, F.M. Li, C. Fang, L.J. Ge, and J.S. Ye. 2018. Benefits and limitations to straw- and plastic-film mulch on maize yield and water use efficiency: A meta-analysis across hydrothermal gradients. Eur. J. Agron. 99:138-147.

Zhang, Y.-L., C.C. Shock, F.-X. Wang, J.-T. Qin, K.-J. Yang, S.-Z. Kang, and S.-E. Li. 2017. Influence of different plastic film mulches and wetted soil percentages on potato grown under drip irrigation. Agr. Water Mgt. 180:160-171.

Zheng, W., Z. Zhao, Q. Gong, B. Zhai, and Z. Li. 2018. Effects of cover crop in an apple orchard on microbial community composition, networks, and potential genes involved with degradation of crop residues in soil. Biol. Fertil. Soils 54(6):743-759. 